\title{
Road-killed toads as a non-invasive source to study age structure of spring migrating population
}

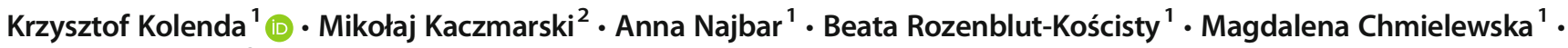 \\ Bartłomiej Najbar $^{3}$
}

Received: 10 May 2018 / Revised: 22 November 2018 / Accepted: 13 December 2018 / Published online: 26 December 2018

(C) The Author(s) 2019

\begin{abstract}
Development of road system causes worldwide barriers to wildlife movement and leads to mass road mortality which is a serious threat to the biodiversity, especially globally endangered amphibians. Animal carcasses, however, constitute an important noninvasive material for further research including species life history traits, but there is little known whether the road-killed animals are a representative sample of entire population. The aim of our research was to compare the age structures between road-killed and live individuals which crossed the road successfully during the breeding migration. As a model species, we used the common toad Bufo bufo which is a main amphibian traffic victim in Europe. We collected toe clips of dead and live toads during their breeding migration in four sampling sites located in the lowlands of western Poland. Phalanges were used for age determination by the skeletochronology. There were no significant differences in age distribution between live and dead individuals of the same sex in all populations studied. In compared groups, medians and mean ages were the same or differed marginally and confidence intervals for the mean age almost completely overlapped. Our results suggest that toads are killed on roads regardless of individual age, thus skeletochronological analysis of dead individuals is useful to study age structure of a live population. Our approach allows to avoid mutilation of amphibians and can be used to increase the knowledge of age structure of a given species living near the road as well as to study long-term road effect on amphibian demography. However, further comparative research on different species is required.
\end{abstract}

Keywords Amphibians $\cdot$ Bufo bufo $\cdot$ Demography $\cdot$ Life history $\cdot$ Road mortality $\cdot$ Skeletochronology

\section{Introduction}

Expansion of road network strongly influences wildlife around the world (Balkenhol and Waits 2009; Ward

This article is part of the Topical Collection on Road Ecology Guest Editor: Marcello D'Amico

Electronic supplementary material The online version of this article (https://doi.org/10.1007/s10344-018-1240-8) contains supplementary material, which is available to authorized users.

Krzysztof Kolenda

krzysztof.kolenda@uwr.edu.pl

1 Department of Evolutionary Biology and Conservation of Vertebrates, Faculty of Biological Sciences, University of Wrocław, Sienkiewicza 21, 50-335 Wrocław, Poland

2 Institute of Zoology, Poznan University of Life Sciences, Wojska Polskiego 71 C, 60-625 Poznań, Poland

3 Faculty of Biological Sciences, University of Zielona Góra, Szafrana 1, 65-516 Zielona Góra, Poland et al. 2015; Ibisch et al. 2016). It is pointed out that road mortality is the most severe consequence of habitat split (Baxter-Gilbert et al. 2015; Skórka et al. 2015), and can be responsible for elimination of individuals with good body condition from populations (Bujoczek et al. 2011). The most common traffic victims, as well as the most negatively affected by roads among vertebrates, are amphibians (Hels and Buchwald 2001; Glista et al. 2008; Beckmann and Shine 2015), which at the same time are one of the most threatened taxonomic group worldwide (Stuart et al. 2004). Despite this, amphibians are one of the least studied vertebrates in the context of roads impact on populations (Rytwinski and Fahrig 2012).

The road-killing of amphibians is an unresolved problem in a global scale (Beebee 2013). This phenomenon may be an opportunity to examine many aspects of road effects on animals (Santos et al. 2011, 2015; Cosentino et al. 2014; D'Amico et al. 2015). Moreover, road carcasses can be used to study species distribution, habitat preferences, or phenology (Orłowski 2007; Sutherland et al. 2010). They are also a 
potential non-invasive alternative to obtain material for further research, including genetic analysis (Balkenhol and Waits 2009), detection of amphibians' diseases (Martel et al. 2012), trace elements in bones (Simon et al. 2012), or histology and age structure (Kaczmarski et al. 2016). Although this approach could limit invasive methods, the data obtained from road kills may be biased due to removal of carcasses from roads by scavengers (Antworth et al. 2005). Comparative data concerning road-killed animals and live populations is scarce (Loughry and McDonough 1996) and there is no certainty whether road kills are a representative sample of entire population, and to what extent are they useful to conduct noninvasive research of their life history traits.

Studies on population age structure are crucial to investigate age of maturity, longevity including reproductive life span, mortality, growth rate, and fecundity (Reading 1991; Smirina 1994; Socha and Ogielska 2010). They are also important in understanding the species population dynamics (Hemelaar 1986; Smirina 1994; Middleton and Green 2015). Amphibian body length and mass are more dependent on environmental factors and individual predispositions, thus these parameters should not be used to estimate precise age (Hemelaar 1986; Reading 1991). Consequently, the most reliable method to estimate individual age irrespective of body dimensions is skeletochronology (Smirina 1994; Ogielska et al. 2006). It is based on lines of arrested growth (LAGs) formed in the periosteum of the long bones during hibernation when bone tissue apposition stops. Long bones, especially phalanges, are the most useful skeletal elements for this method (Smirina 1994), thus dead amphibians provide possibility to collect the material without mutilating live animals.

Furthermore, amphibians are very sensitive to negative impact of the human activities, therefore studies of the age structure dynamics can be used in biomonitoring, including effect of climate change, or in estimating probability of threatened populations extinction (Guarino et al. 2008; Middleton and Green 2015; Sinsch 2015). These studies are essential for developing suitable conservation plans for populations, and species management in their natural environments (Driscoll 1999). Large-scale and long-term studies can show such dependencies (Tryjanowski et al. 2003, 2006); however, if possible, they should be carried out with a minimum degree of invasiveness.

In this study, we tested the hypothesis that age structure of road-killed common toads and live individuals which crossed the road successfully during a breeding migration does not significantly differ. We also suggest that the age estimation of road-killed amphibians may be applicable to studies of current structure of an adjacent live population, thereby constituting non-invasive approach and allowing to avoid stress and mutilation of live animals.

\section{Materials and methods}

\section{Model species}

The common toad Bufo bufo is an example of explosively breeding amphibian (Gittins 1983). Depending on the weather condition, their breeding migration generally lasts between 10 days and 1 month (Gittins 1983; Juszczyk 1987). According to the International Union for Conservation of Nature (IUCN), B. bufo is common over majority of its range, listed as least concern and population trend as being stable (Agasyan et al. 2009). Previously, it was used to conduct research on a wide range of spatial and temporal scales (Tryjanowski et al. 2003; Sparks et al. 2007). B. bufo is also a main victim among amphibian road kills in Europe (Beebee 2013), including Poland (Gryz and Krauze 2008; Elzanowski et al. 2009). Its vulnerability to road mortality is higher than in other amphibian species because of short and explosive reproduction, tendency for long distance migration, and philopatry, as well as widespread occurrence even in human-altered habitat due to their plasticity (Reading et al. 1991; Hels and Buchwald 2001; Orłowski 2007). Toad carcasses can remain on the roads over a dozen days or sometimes even several weeks, due to their large sizes, tough skin, and toxicity (Santos et al. 2011), and thus it can be one of the best amphibian species offering various examinations based on material from animal collisions with vehicles. However, recent data have shown populations decline in several countries such as the UK (Carrier and Beebee 2003; Petrovan and Schmidt 2016), Italy (Bonardi et al. 2011), or Switzerland (Petrovan and Schmidt 2016), also caused by long-term effect of road mortality in the UK (Cooke 2011).

\section{Data collection}

We conducted field survey in 2016 and 2017 in the lowlands of western Poland, Central Europe. Based on our previous field observations, we localized four road mortality hotspots in nonoverlapping sampling sites. Using QGIS 2.4 (Quantum GIS Development Team 2014) and the orthophotomaps (provided by Head Office of Geodesy and Cartography; http://www. geoportal.gov.pl/), we assessed the land cover classification of each site studied within a $500 \mathrm{~m}$ buffer area surrounding central point of road mortality, taking into account the average range of space used by species traits (Guillot et al. 2016; Salazar et al. 2016; see Online Resource for details). Thus, we classified each site as follows: 1-suburban site (Ochla), constituted estate of detached houses near Zielona Góra city; 2-suburban site (Maślice), district in the suburban part of Wrocław city comprised artificial pond in park surrounded by estate of detached houses; 3-forest site (Łagów), forest area placed near Łagowskie and Ciche Lakes; and 4-rural site (Brody), rural area near Nabłoto fish ponds (Fig. 1, see Table 1 for geographic coordinates and $\mathrm{m}$ a.s.l.). 
In sites 1 and 2, we collected toads throughout the entire amphibian migration period (an average of 10-17 days), but in sites 3 and 4 only during one evening at the middle of migration time. An hour after dark, we captured by hand all encountered live toads, that crossed the road which intersects their migration routes, and dead ones killed due to collision with vehicles. We determined sex of live and dead individuals directly in the field (according to Kaczmarski et al. 2016). We identified males by the occurrence of the nuptial pad, whereas females by ovaries and eggs (dead individuals) and auxiliary also by body size and shape.

We cut off the 4th toe of the hind limb from each individual using microsurgical scissors, sterilized each time before use (only in case of live toads). We disinfected the resulting wound in live toads with $0.01 \%$ potassium permanganate. After the procedure, we immediately released live individuals to their habitat.

\section{Skeletochronological analysis}

We stored the toes in Eppendorf tubes with $80 \%$ ethanol. We performed skeletochronological analysis according to Rozenblut and Ogielska (2005) with some modifications in protocol (see Kaczmarski et al. 2016 for details). After removing the soft tissue, we decalcified phalanges in 1:1 mixture of $10 \%$ formic acid and $4 \%$ formalin for a maximum of $4 \mathrm{~h}$. We froze decalcified phalanges, sliced them into $10-\mu \mathrm{m}$ thick sections by freezing microtome, and stained in $0.05 \%$ cresyl violet. For age evaluation, we counted the number of LAGs, deposited in periosteal bone during each hibernation $(1 \mathrm{LAG}=1$ hibernation $=1$ year of life) (Smirina 1994; Rozenblut and Ogielska 2005). Since we have collected the toads shortly after hibernation, we counted the bone outer margin as the last LAG (Rogers and Harvey 1994). We examined at least 20 cross sections of central part of a diaphysis per individual (Sinsch 2015). We performed analysis of histological samples under Carl Zeiss Axioscope 20 light microscope at different magnifications, ranging from $\times 10$ to $\times 40$, and we took selected images of sections with a Carl Zeiss Axiocam Color Microscope Camera.

\section{Statistical analysis}

In order to estimate intra-observer error, we measured Spearman's rank correlation coefficient, within one observer (K.K.) and among two observers (K.K. and B.R-K.) for 30 randomly chosen individuals. In both cases, age estimation agreed (Spearman's rho, within K. K.: $r=0.89 p<0.05$, between K. K and B. R-K.: $r=0.82 p<0.05$, respectively).

We used two-sampled Kolmogorov-Smirnov test to compare age distribution between live and dead toads of the same sex. Due to insufficient sample size of females from sites 3 and 4, we have excluded them from statistical analysis. Statistical significance was defined when $p<0.05$. The statistical analysis was performed using SPSS software, version 20.

\section{Results}

We collected 473 toads including 238 live and 235 dead individuals (see Table 1 for details). Age estimation by

Fig. 1 Map showing localization of sampling points of the common toads Bufo bufo (numbers of locations according to Table 1): 1-Ochla, 2-Maślice, 3-Lagów, 4-Brody). Abbreviations: PL-Poland; GR-Germany; CZ-Czechia; SL-Slovakia; UA-Ukraine; BY-Belarus; LT-Latvia

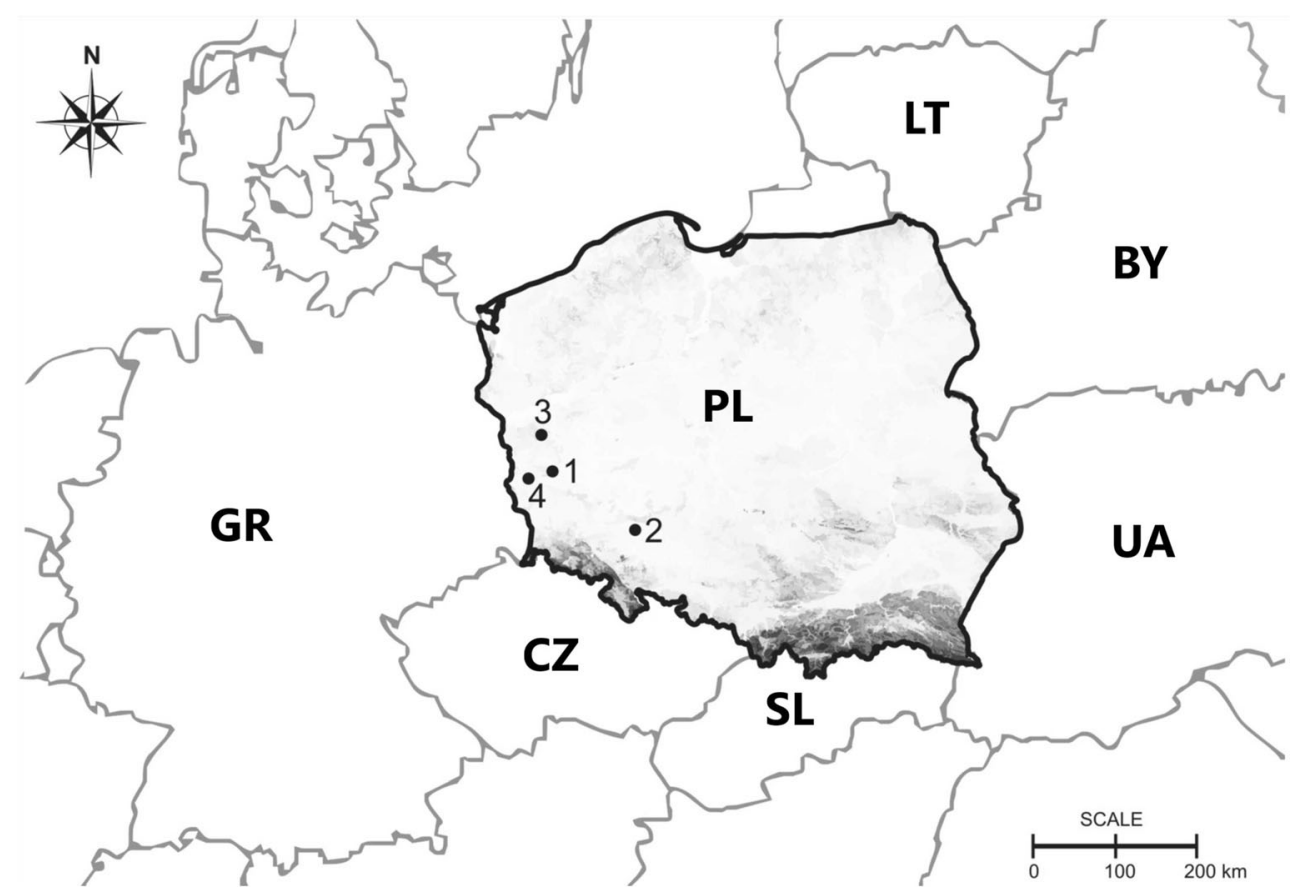


skeletochronology was successful in all examined individuals. LAGs were clearly visible in cross sections of periosteal bone as complete and sharp, circular lines.

In all studied populations, medians and mean ages in live and dead individuals of the same sex were similar or differed marginally (Table 1, Figs. 2 and 3). Confidence interval for the mean age almost completely overlapped as well. KolmogorovSmirnov test revealed no significant differences in age distribution between live and dead individuals of the same sex from sites 1 and 2, as well as between live and dead males from sites 3 and 4

In a suburban site 1 (Ochla), mean age \pm SD of live and dead males was $4.88 \pm 0.89$ and $4.88 \pm 1.39$ years respectively (Table 1). Toads reached the age from 3 to 7 and from 3 to 9 years respectively. In both groups, 4- and 5-year-old individuals dominated (Figs. 2 and 3$)$. Live females $(5.82 \pm 1.59)$ were slightly older then dead ones $(5.72 \pm 1.64)$ (Table 1). Age distribution ranged from 3 to 9 and from 3 to 10 years for live and dead individuals, respectively, without clearly dominating age classes (Figs. 2 and 3).

In a suburban site 2 (Maślice), mean age of live and dead males was $4.39 \pm 1.04$ and $4.32 \pm 1.06$ years respectively (Table 1). Age ranged from 3 to 8 in live and from 3 to 7 years in dead toads. Among them, 4- and 5-year-old individuals were predominant group (Figs. 2 and 3). Mean age of live and dead females was $5.75 \pm 1.2$ and $5.35 \pm 1.23$, respectively (Table 1). Age ranged from 3 to 9 years in live and from 3 to 8 years in dead toads. In both groups, 5- and 6-year females were prevailing. Among live and dead males, medians were the same, whereas among females differed marginally (Table 1, Figs. 2 and 3).

In a forest site 3 (Łagów), mean age of live and dead males was $4.52 \pm 1.6$ and $4.00 \pm 0.8$ years, respectively (Table 1). Age ranged from 3 to 7 in live and from 3 to 6 years in dead toads. Mean age of live and dead females was $5.7 \pm 1.5$ and $6.2 \pm 1.92$, respectively, and ranged from 3 to 9 years in live and from 4 to 8 years in dead toads (Fig. 2).

In a rural site 4 (Brody), mean age of live and dead males was $4.28 \pm 0.98$ and $4.00 \pm 0.7$ respectively (Table 1). Age ranged from 3 to 9 in live and from 3 to 5 years in dead toads. Mean age of live and dead females was $5.75 \pm 1.89$ and $5.5 \pm$ 0.58 , respectively, and ranged from 5 to 9 in live and from 3 to 7 years in dead toads (Fig. 2).

\section{Discussion}

\section{Age structure of live and road-killed toads}

Our results confirmed the hypothesis that age structure of road-killed common toads and live individuals, which crossed the road during the breeding migration, did not significantly differ. Both males and females of the common toad were

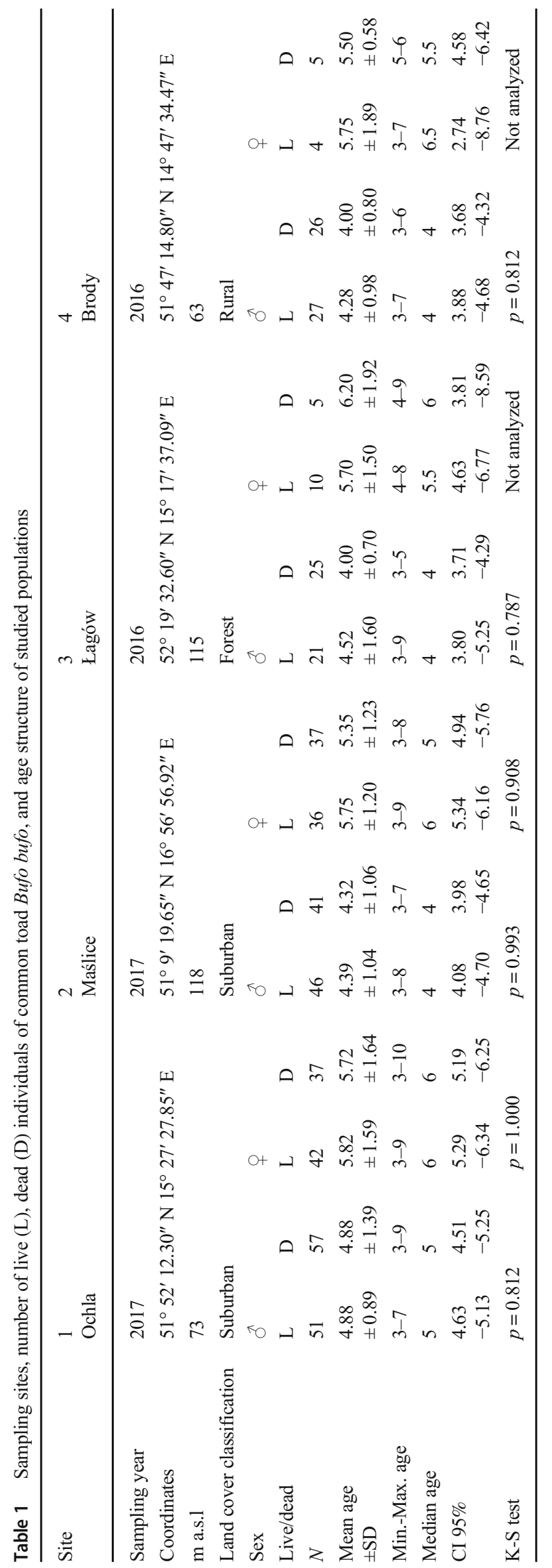


Fig. 2 Age distribution of common toads Bufo bufo used in this study
Live toads

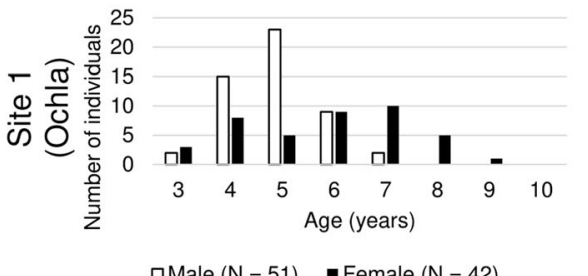

aMale $(N=51) \quad$ - Female $(N=42)$
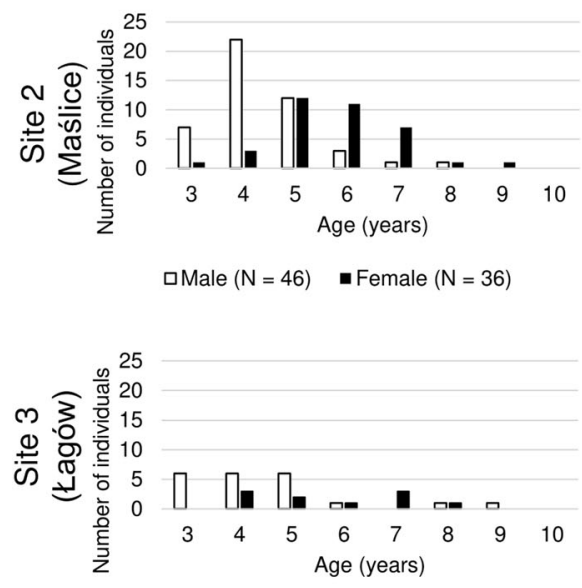

aMale $(\mathrm{N}=21) \quad$ - Female $(\mathrm{N}=10)$

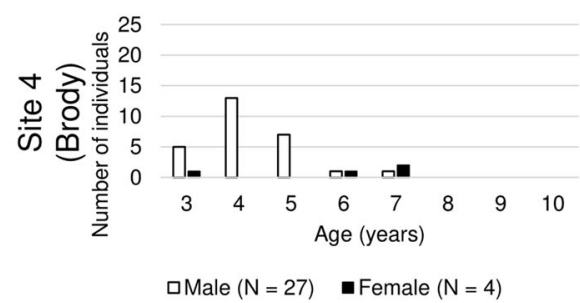

Road-killed toads

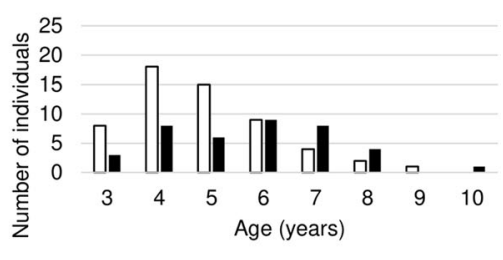

口Male ( $N=57) \quad$-Female $(N=39)$

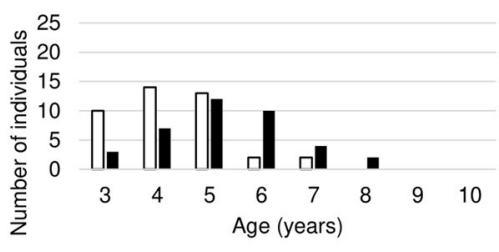

aMale $(\mathrm{N}=41) \quad$ Female $(\mathrm{N}=37)$

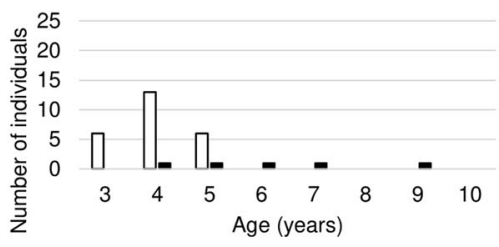

aMale $(\mathrm{N}=25) \quad$ Female $(\mathrm{N}=5)$

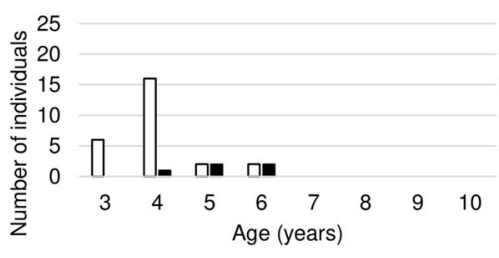

$\square$ Male $(\mathrm{N}=26) \quad \square$ Female $(\mathrm{N}=5)$ killed on roads regardless of the individual age. Age distribution among live and dead toads almost completely overlapped in all studied populations. Similar results were previously reported for a mammal species, the nine-banded armadillo (Dasypus novemcinctus), by Loughry and McDonough (1996), although the authors stated that road-killed individuals are representative demographic sample of the adults, but not of the whole population. They found almost no juvenile carcasses, while they were observed in adjacent live population. However, in our study, we focused on breeding migrating population of common toads, therefore we detected only sexually mature individuals (Kaczmarski et al. 2016; Hemelaar 1986). Juvenile toads do not migrate to breeding ponds, nevertheless, we cannot exclude the possibility of finding roadkilled young individuals migrating to foraging habitat in different locations. However, they are less likely to be eliminated by vehicle collisions than adult ones (Orłowski 2007; Brzezinski et al. 2012).

It was shown recently that various habitats could affect the intensity of migration (Orłowski et al. 2008) and influence the morphology of amphibians (Guillot et al. 2016), as well as their life history traits (Sinsch et al. 2007), but less frequently age structure (Kaczmarski et al. 2016). However, despite of differences in habitat type presented in our study (suburban, forest, rural), toads were killed by vehicles in a random manner at all study sites.

Our results revealed that the age of migrating toads varied between 3 and 10 years. Because the life expectancy of individuals taking part in reproduction is approximately 8 years in lowlands, and up to 18 years at higher altitudes (Hemelaar 1986), we conclude that the individuals in our study fitted in this range and may constitute a part of breeding population.

\section{Skeletochronological interpretation}

Skeletochronological analysis using the bone material from phalanges allowed us to evaluate individual age in all roadkilled toads. Previous research revealed $95 \%$ possibility of age estimation on the basis of road-killed individuals (Kaczmarski et al. 2016). In some studies, material obtained from live 
Fig. 3 Comparison of age distribution between live and dead common toads Bufo bufo of the same sexes from Ochla and Maślice locations
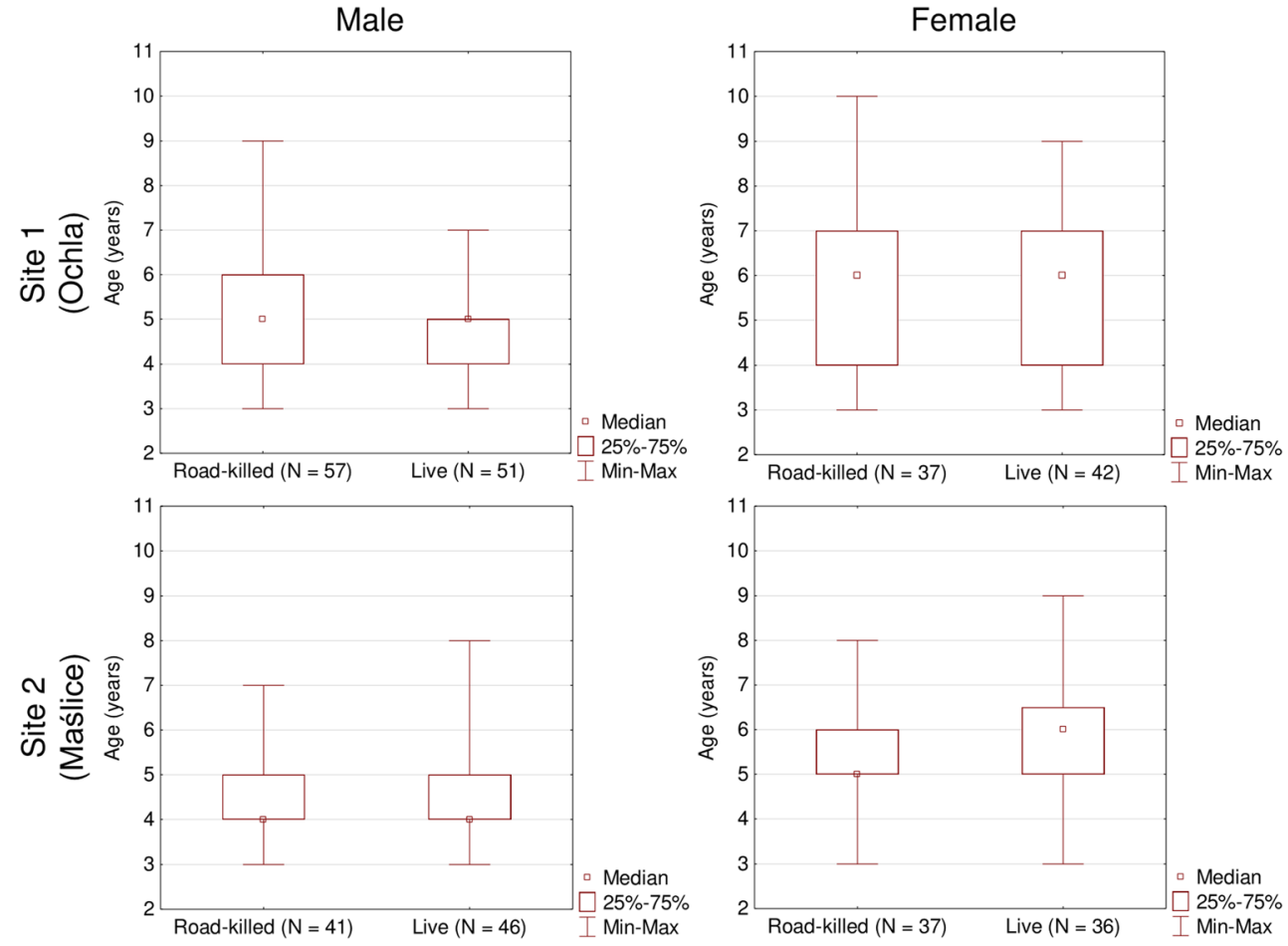

amphibians did not allow to assess age for all studied individuals. For example, Cvetković et al. (2005) could not determine age in $14(12.3 \%)$ out of 114 samples. Such problems are usually caused by insufficient bone decalcification, inaccurate cross sectioning resulting in low sample quality, and poor affinity for stain used, as well as high concentration of anomalies in the periosteal bone resulting in indistinct or almost invisible resting lines (Cvetković et al. 2005; Kaczmarski et al. 2016). Thus, method based on phalanges from roadkilled amphibians can be successfully used in the study of their age structure, while respecting an appropriate protocol to prepare the material.

\section{Use of road kills for scientific purposes}

Although we found no significant differences in age structure between road kills and live toads, we cannot be sure if dead toads are representative sample of the breeding population. In fact, we do not know whether our sample areas were the only path the toads used to access the breeding ponds (this is the individual feature of each population). We would provide a stronger representative sample of the actual breeding population if the live toads were collected directly from breeding ponds. Such an approach should be the subject of future investigation, especially, that if the road-killed toads are truly representative of the breeding population then their carcasses would be also a representative source for tissue samples for future needs, e.g., genetics studies.
In spite of all, confirmation of our assumption has opened a new way to broad-scale studies. In contrast to obtaining material from live animals, using toe clips from carcasses does not cause mutilation of living individuals from given population and does not require permissions from ethical commissions. Although toe clipping is a widely accepted and costeffective technique for marking individuals (it especially enables obtaining material for further studies such as age assessment), the effect on amphibian survival varies among species and is still under debate (McCarthy and Parris 2004; Funk et al. 2005; Perry et al. 2011). In our opinion, the main limitation of non-invasive research based on road-killed amphibians is availability of material from required sites. However, worldwide fragmentation of landscape rapidly increases resulting in deterioration of the connection between habitats (Ibisch et al. 2016). In combination with amphibians' urge to reproduce and cross the roads massively, it causes huge mortality of many species from different habitats (Elzanowski et al. 2009; Orłowski et al. 2008; Beebee 2013). The vast majority of amphibians cannot create avoidance mechanisms that could protect them from road mortality, and immobility is their only response to the approaching vehicles (Mazerolle et al. 2005; Bouchard et al. 2009). On the other hand, according to Grace et al. (2017), species with lower reproductive rate are less abundant roadside than those with higher one, and thus are potentially less vulnerable to roadkill effect. Furthermore, some amphibians are very rare victims of collisions with vehicles as the traffic noise impairs their breeding migration behavior (Tennessen et al. 2014). In such cases, our 
approach would probably not be effective. It is also important to note that toads, thanks to their features, especially toxicity (Kowalski et al. 2018), are inedible for many scavengers and can remain longer on the road than other amphibians. Thus, similar studies on the basis of different species, such as ranids, salamandrids, and other pool-breeding amphibians, should be carried out, as well, but interpretation of resulting data requires more caution. For better understanding of amphibian road mortality phenomenon, studies of their age structure should be conducted on both road-killed individuals and in populations not threatened by traffic, especially that long-term impact of roads as well as various different factors may disturb the structure of population. In fact, all papers reviewed by Rytwinski and Fahrig (2015) showed negative road impact on amphibians, regardless of their life history traits.

Current knowledge of amphibian age structure includes above 200 species, predominantly anurans, but data for many species is still limited to some subpopulations or individual site and derived mostly from temperate zones (Sinsch 2015). However, demographic data is crucial for better understanding of the human role in amphibians' decline (Petrovan and Schmidt 2016). Long-term skeletochronological investigations into many populations in broad spatial scale are necessary, in order to estimate their response to human-made changes in the environment, including new road infrastructure development, and to distinguish them from natural geographical variation or impact of climate change. Our approach provides both, study of the current age structure of migrating population under road pressure of a given species and/or collecting long-term data to evaluate age-related population trends. Indeed, using such demographic data, we can predict how human pressure and environmental factors may contribute to changes within amphibian population or even to their extinction. Some life history traits such as age of maturity, longevity, or potential reproductive life span are good indicators of habitat quality (Sinsch et al. 2007). As demonstrated, continuous road mortality causes the decline in numbers of individuals in amphibian populations (Gibbs and Shriver 2005; Cooke 2011) and, according to Middleton and Green (2015), as the population decreases, the mean age increases as the result of lower recruitment.

Finally, knowledge of amphibian age structure in locations of increased mortality rates can contribute to protection and management of the most endangered populations. Indeed, thanks to this, we can indicate which populations require immediate protection and take action before population collapse. In cooperation with environmental NGOs, conservationists, and local authorities, we can focus our effort on most threatened populations, especially in the face of limited financial resources.

\section{Conclusions}

We would like to emphasize that this study is a step towards better understanding of roads and traffic impact on the amphibians. The age structure is another necessary but neglected indicator of population status besides already established measures such as body condition (morphometry) and more innovative ones as the estimation of the stress hormone levels (Janin et al. 2011). Amphibian mass road mortality increases with the development of infrastructure and is faster than mitigation action. It allows us to prepare longterm data sets that can be used in the future for estimation of large-scale trends. Volunteers taking part in amphibian conservation actions in many countries are an invaluable asset for collecting census data (Bonardi et al. 2011; Petrovan and Schmidt 2016), and material from road carcasses, necessary for the age structure investigation. The use of road-killed amphibians in the aforementioned study has the added benefit of field scientists avoiding contact with live specimens during data collection, thus limiting transfer of infectious diseases responsible for worldwide amphibian decline (Phillott et al. 2010). However, further research conducted on other species vulnerable to road mortality around the world is needed to assess the possibility of using their carcasses in the context of entire population.

Acknowledgements We thank M. Ogielska for the idea of this manuscript. We also thank P. Tryjanowski for his valuable comments on this manuscripts and M. Frydlewicz for her help during field work. We also thank Guest Editor and three anonymous Reviewers for their useful comments which greatly improved the article.

Funding information K.K. was financially supported by Polish Ministry of Science and Higher Education (Grant number 0420/1408/16).

Compliance with ethical standardsAll procedures were performed under permits from the General Directorate of Environmental Protection (permission no. WZP-WG.6401.02.4.2016.JRO) and II Local Ethical Commission for Animal Experiments in Wrocław (permission no. 2/2015).

Open Access This article is distributed under the terms of the Creative Commons Attribution 4.0 International License (http:// creativecommons.org/licenses/by/4.0/), which permits unrestricted use, distribution, and reproduction in any medium, provided you give appropriate credit to the original author(s) and the source, provide a link to the Creative Commons license, and indicate if changes were made.

Publisher's Note Springer Nature remains neutral with regard to jurisdictional claims in published maps and institutional affiliations.

\section{References}

Agasyan A, Avisi A, Tuniyev B, Crnobrnja Isailovic J, Lymberakis P, Andrén C, Cogalniceanu D, Wilkinson J, Ananjeva N, Üzüm N, Orlov N, Podloucky R, Tuniyev S, Kaya U (2009) Bufo bufo. The IUCN Red List of Threatened Species 2009: e.T54596A11159939. https://doi.org/10.2305/IUCN.UK.2009.RLTS.T54596A11159939. en. Downloaded on 07 February 2018 
Antworth RL, Pike DA, Stevens EE (2005) Hit and run: effects of scavenging on estimates of roadkilled vertebrates. Southeast Nat 4:647656. https://doi.org/10.1656/1528-7092(2005)004[0647: HAREOS]2.0.CO;2

Balkenhol N, Waits LP (2009) Molecular road ecology: exploring the potential of genetics for investigating transportation impacts on wildlife. Mol Ecol 18:4151-4164. https://doi.org/10.1111/j.1365294X.2009.04322.X

Baxter-Gilbert JH, Riley JL, Neufeld CJH, Litzgus JD, Lesbarreres D (2015) Road mortality potentially responsible for billions of pollinating insect deaths annually. J Insect Conserv 19:1029-1035. https://doi.org/10.1007/s10841-015-9808-z

Beckmann C, Shine R (2015) Do the numbers and locations of roadkilled anuran carcasses accurately reflect impacts of vehicular traffic? J Wildl Manag 79:92-101. https://doi.org/10.1002/jwmg.806

Beebee TJC (2013) Effects of road mortality and mitigation measures on amphibian populations. Conserv Biol 27:657-668. https://doi.org/ 10.1111/cobi.12063

Bonardi A, Manenti R, Corbetta A, Ferri V, Fiacchini D, Giovine G, Macchi S, Romanazzi E, Soccini C, Bottoni L, Padoa-Schioppa E, Ficetola GF (2011) Usefulness of volunteer data to measure the large sale decline of "common" toad populations. Biol Conserv 144: 2328-2334. https://doi.org/10.1016/j.biocon.2011.06.011

Bouchard JA, Ford T, Eigenbrod FE, Fahrig L (2009) Behavioral responses of northern leopard frogs (Rana pipiens) to roads and traffic: implications for population persistence. Ecol Soc 14:23 https:// www.ecologyandsociety.org/vol14/iss2/art23/

Brzezinski M, Eliava G, Żmihorski M (2012) Road mortality of pondbreeding amphibians during spring migrations in the Mazurian Lakeland, NE Poland. Eur J Wildl Res 58:685-693. https://doi. org/10.1007/s10344-012-0618-2

Bujoczek M, Ciach M, Yosef R (2011) Road-kills affect avian population quality. Biol Conserv 144:1036-1039. https://doi.org/10.1016/j. biocon.2010.12.022

Carrier J-A, Beebee TJC (2003) Recent, substantial and unexplained declines of the common toad Bufo bufo in lowland England. Biol Conserv 111:395-399. https://doi.org/10.1016/S0006-3207(02) 00308-7

Cvetković DD, Tomašević N, Aleksić ID, Crnobrnja-Isailović JM (2005) Assessment of age and intersexual size differences in Bufo bufo. Arch Biol Sci 57:157-162.

Cooke AS (2011) The role of road traffic in the near extinction of common toads (Bufo bufo) in Ramsey and Bury. Nature in Cambridgeshire 53:45-50

Cosentino BJ, Marsh DM, Jones KS, Apodaca JJ, Bates C, Beach J, Beard KH, Becklin K, Bell JM, Crockett C, Fawson G, Fjelsted J, Forys EA, Genet KS, Grover M, Holmes J, Indeck K, Karraker NE, Kilpatrick E, Langen TA, Mugel SG, Molina A, Vonesh JR, Weaver R, Willey A (2014) Citizen science reveals widespread negative effects of roads on amphibian distributions. Biol Conserv 180:3138. https://doi.org/10.1016/j.biocon.2014.09.027

D’Amico M, Roman J, de los Reyes L, Revilla E (2015) Vertebrate roadkill patterns in Mediterranean habitats: who, when and where. Biol Conserv 191:234-242. https://doi.org/10.1016/j.biocon.2015.06. 010

Driscoll DA (1999) Skeletochronological assessment of age structure and population stability for two threatened frog species. Austral Ecol 24: 182-189. https://doi.org/10.1046/j.1442-9993.1999.241961.x

Elzanowski A, Ciesiołkiewicz J, Kaczor M, Radwańska J, Urban R (2009) Amphibian road mortality in Europe: a meta-analysis with new data from Poland. Eur J Wildl Res 55:33-43. https://doi.org/10. 1007/s10344-008-0211-x

Funk WC, Donnelly MA, Lips KR (2005) Alternative views of amphibian toe-clipping. Nature 433:193. https://doi.org/10.1038/433193c
Gibbs JP, Shriver WG (2005) Can road mortality limit populations of pool-breeding amphibians? Wetl Ecol Manag 13:281-289. https:// doi.org/10.1007/s11273-004-7522-9

Gittins SP (1983) The breeding migration of the common toad (Bufo bufo) to a pond in mid-Wales. J Zool 199:555-562. https://doi. org/10.1111/j.1469-7998.1983.tb05106.x

Glista DJ, De Vault TL, De Woody JA (2008) Vertebrate road mortality predominantly impacts amphibians. Herpetol Conserv Biol 3:77-87

Grace MK, Smith DJ, Noos RF (2017) Roadside abundance of anurans within a community correlates with reproductive investment. Front Ecol Evol 5:65. https://doi.org/10.3389/fevo.2017.00065

Gryz J, Krauze D (2008) Mortality of vertebrates on a road crossing the Biebrza Valley (NE Poland). Eur J Wildl Res 54:709-714. https:// doi.org/10.1007/s10344-008-0200-0

Guarino FM, Di Gia I, Sindaco R (2008) Age structure in a declining population of Rana temporaria from northern Italy. Acta Zool Acad Sci Hung 54:99-112

Guillot H, Boissinot A, Angelier F, Lourdais O, Bonnet X, Brischoux F (2016) Landscape influences the morphology of male common toads (Bufo bufo). Agric Ecosyst Environ 233:106-110. https:// doi.org/10.1016/j.agee.2016.08.032

Hels T, Buchwald E (2001) The effect of road kills on amphibian populations. Biol Conserv 99:331-340. https://doi.org/10.1016/S00063207(00)00215-9

Hemelaar A (1986) Demographic study of Bufo bufo L. (Anura, Amphibia) from different climates, by means of skeletochronology. Dissertation. University of Nijmenen

Ibisch PL, Hoffmann MT, Kreft S, Peer G, Kati V, Biber-Freudenberger L, Della Sala DA, Vale MM, Hobson PR, Selva N (2016) A global map of roadless areas and their conservation status. Science 354: 1423-1427. https://doi.org/10.1126/science.aaf7166

Janin A, Léna JP, Joly P (2011) Beyond occurrence: body condition and stress hormone as integrative indicators of habitat availability and fragmentation in the common toad. Biol Conserv 144:1008-1016. https://doi.org/10.1016/j.biocon.2010.12.009

Juszczyk W (1987) Płazy i gady krajowe. Część 2. Płazy - Amphibia. Warszawa, Poland, Państwowe Wydawnictwo Naukowe. [in Polish]

Kaczmarski M, Kolenda K, Rozenblut-Kościsty B, Sośnicka W (2016) Phalangeal bone anomalies in the European common toad Bufo bufo from polluted environments. Environ Sci Pollut Res 23:21940 21946. https://doi.org/10.1007/s11356-016-7297-6

Kowalski K, Marciniak P, Rosiński G, Rychlik L (2018) Toxic activity and protein identification from the parotoid gland secretion of the common toad Bufo bufo. Comp Biochem Physiol C Toxicol Pharmacol 20:543-552. https://doi.org/10.1016/j.cbpc.2018.01.004

Loughry WJ, McDonough CM (1996) Are road-kills valid indicators of armadillo population structure? Am Midl Nat 135:53-59. https:// doi.org/10.2307/2426871

Martel A, Fard MS, Van Rooij P, Jooris R, Boone F, Haesebrouck F, Van Rooij D, Pasmans F (2012) Road-killed common toads (Bufo bufo) in Flanders (Belgium) reveal low prevalence of ranaviruses and Batrachochytrium dendrobatidis. J Wildl Dis 48:835-839. https:// doi.org/10.7589/0090-3558-48.3.835

Mazerolle MJ, Huot M, Gravel M (2005) Behavior of amphibians on the road in response to car traffic. Herpetologica 61:380-388. https:// doi.org/10.1655/04-79.1

McCarthy MA, Parris KM (2004) Clarifying the effect of toe clipping on frogs with Bayesian statistics. J Appl Ecol 41:780-786. https://doi. org/10.1111/j.0021-8901.2004.00919.x

Middleton J, Green DM (2015) Adult age-structure variability in an amphibian in relation to population decline. Herpetologica 71:190 195. https://doi.org/10.1655/HERPETOLOGICA-D-14-00074

Ogielska M, Rozenblut B, Berger L, Kierzkowski P (2006) Actual and skeletochronologically estimated age of species and hybrids of European water frogs. Zool Pol 51:51-61 
Orłowski G (2007) Spatial distribution and seasonal pattern in road mortality of the common toad Bufo bufo in an agricultural landscape of south-western Poland. Amphibia-Reptilia 28:25-31. https://doi.org/ 10.1163/156853807779799045

Orłowski G, Ciesiołkiewicz J, Kaczor M, Radwańska J, Żywicka A (2008) Species composition and habitat correlates of amphibian road-kills in different landscapes of south-western Poland. Pol J Ecol 56:659-671

Perry G, Wallace MC, Perry D, Curzer H, Muhlberge P (2011) Toe clipping of amphibians and reptiles: science, ethics, and the law. $\mathrm{J}$ Herpetol 45:547-555. https://doi.org/10.1670/11-037.1

Petrovan SO, Schmidt BR (2016) Volunteer conservation action data reveals large-scale and long-term negative population trends of a widespread amphibian, the common toad (Bufo bufo). PLoS One 11:e0161943. https://doi.org/10.1371/journal.pone.0161943

Phillott AD, Speare R, Hines HB, Skerratt LF, Meyer E, Mc-Donald KR, Cashins SD, Mendez D, Berger L (2010) Minimising exposure of amphibians to pathogens during field studies. Dis Aquat Org 92: 175-185. https://doi.org/10.3354/dao02162

Reading CJ (1991) The relationship between body length, age and sexual maturity in the common toad, Bufo bufo. Ecography 14:245-249. https://doi.org/10.1111/j.1600-0587.1991.tb00658.x

Reading CJ, Loman J, Madsen T (1991) Breeding pond fidelity in the common toad, Bufo bufo. J Zool 225:201-211. https://doi.org/10. 1111/j.1469-7998.1991.tb03811.x

Rogers KL, Harvey L (1994) A skeletochronological assessment of fossil and recent Bufo cognatus from south-central Colorado. J Herpetol 28:133-140. https://doi.org/10.2307/1564611

Rozenblut B, Ogielska M (2005) Development and growth of long bones in European water frogs (Amphibia: Anura: Ranidae), with remarks on age determination. J Morphol 265:304-317. https://doi.org/10. 1002/jmor.10344

Rytwinski T, Fahrig L (2012) Do species life history traits explain population responses to roads? A meta-analysis. Biol Conserv 147:8798. https://doi.org/10.1016/j.biocon.2011.11.023

Rytwinski T, Fahrig L (2015) The impacts of roads and traffic on terrestrial animal populations. In: van de Ree R, Grilo C, Smith D (eds) Handbook for road ecology. Wiley-Blackwell, Hoboken, pp 237246

Salazar RD, Montgomery RA, Thresher SE, Macdonald DW (2016) Mapping the relative probability of common toad occurrence in terrestrial lowland farm habitat in the United Kingdom. PLoS One 11:e148269. https://doi.org/10.1371/journal.pone.0148269

Santos SM, Carvalho F, Mira A (2011) How long do the dead survive on the road? Carcass persistence probability and implications for roadkill monitoring surveys. PLoS One 6:e25383. https://doi.org/10. 1371/journal.pone. 0025383

Santos SM, Marques JT, Lourenco A, Medinas D, Barbosa AM, Beja P, Mira A (2015) Sampling effects on the identification of roadkill hotspots: implications for survey design. J Environ Manag 162: 87-95. https://doi.org/10.1016/j.jenvman.2015.07.037

Simon E, Puky M, Braun M, Tóthmérész B (2012) Assessment of the effects of urbanization on trace elements of toe bones. Environ Monit Assess 184:5749-5754. https://doi.org/10.1007/s10661011-2378-y

Sinsch U (2015) Review: Skeletochronological assessment of demographic life-history traits in amphibians. Herpetol J 25:5-13

Sinsch U, Leskovar C, Drobig A, Konig A, Grosse WR (2007) Lifehistory traits in green toad (Bufo viridis) populations: indicators of habitat quality. Can J Zool 85:665-673. https://doi.org/10.1139/ Z07-046

Skórka P, Lenda M, Moroń D, Martyka R, Tryjanowski P, Sutherland WJ (2015) Biodiversity collision blackspots in Poland: separation causality from stochasticity in roadkills of butterflies. Biol Conserv 187: 154-163. https://doi.org/10.1016/j.biocon.2015.04.017

Smirina EM (1994) Age determination and longevity in amphibians. Gerontology 40:133-146. https://doi.org/10.1159/000213583

Socha M, Ogielska M (2010) Age structure, size and growth rate of water frogs from central European natural Pelophylax ridibundusPelophylax esculentus mixed populations estimated by skeletochronology. Amphibia-Reptilia 31:239-250. https://doi.org/ $10.1163 / 156853810791069119$

Sparks T, Tryjanowski P, Cooke A, Crick H, Kuźniak S (2007) Vertebrate phenology at similar latitudes: temperature responses differ between Poland and the United Kingdom. Clim Res 34:93-98

Stuart SN, Chanson JS, Cox NA, Young BE, Rodrigues ASL, Fischman DL, Waller RW (2004) Status and trends of amphibian declines and extinctions worldwide. Science 306:1783-1786. https://doi.org/10. 1126/science. 1103538

Sutherland RW, Dunning PR, Baker WM (2010) Amphibian encounter rates on roads with different amounts of traffic and urbanization. Conserv Biol 24:1626-1635. https://doi.org/10.1111/j.1523-1739. 2010.01570.x

Tennessen JB, Parks SE, Langkilde T (2014) Traffic noise causes physiological stress and impairs breeding migration behaviour in frogs. Conserv Physiol 2:1-8. https://doi.org/10.1093/conphys/cou032

Tryjanowski P, Rybacki M, Sparks T (2003) Changes in spawning dates of common frogs and common toads in western Poland in 19782002. Ann Zool Fennici 40:459-464

Tryjanowski P, Sparks T, Rybacki M, Berger L (2006) Is body size of the water frog Rana esculenta complex responding to climate change? Naturwissenschaften 93:110-113. https://doi.org/10.1007/s00114006-0085-2

Ward AI, Dendy J, Cowan DP (2015) Mitigating impacts of roads on wildlife: an agenda for the conservation of priority European protected species in Great Britain. Eur J Wildl Res 61:199-211. https://doi.org/10.1007/s10344-015-0901-0 